\title{
Papers
}

\section{Early growth and coronary heart disease in later life: longitudinal study}

\author{
J G Eriksson, T Forsén, J Tuomilehto, C Osmond, D J P Barker
}

\begin{abstract}
Objective To determine how growth during infancy and childhood modifies the increased risk of coronary heart disease associated with small body size at birth.

Design Longitudinal study.

Setting Helsinki, Finland.

Subjects 4630 men who were born in the Helsinki University Hospital during 1934-44 and who attended child welfare clinics in the city. Each man had on average 18.0 (SD 9.5) measurements of height and weight between birth and age 12 years.

Main outcome measures Hospital admission or death from coronary heart disease.

Results Low birth weight and low ponderal index (birth weight/length ${ }^{3}$ ) were associated with increased risk of coronary heart disease. Low height, weight, and body mass index (weight/height ${ }^{2}$ ) at age 1 year also increased the risk. Hazard ratios fell progressively from $1.83(95 \%$ confidence interval 1.28 to 2.60$)$ in men whose body mass index at age 1 year was below $16 \mathrm{~kg} / \mathrm{m}^{2}$ to 1.00 in those whose body mass index was $>19$ ( $\mathrm{P}$ for trend $=0.0004)$. After age 1 year, rapid gain in weight and body mass index increased the risk of coronary heart disease. This effect was confined, however, to men with a ponderal index $<26$ at birth. In these men the hazard ratio associated with a one unit increase in standard deviation score for body mass index between ages 1 and 12 years was 1.27 ( 1.10 to $1.47 ; \mathrm{P}=0.001)$.

Conclusion Irrespective of size at birth, low weight gain during infancy is associated with increased risk of coronary heart disease. After age 1 year, rapid weight gain is associated with further increase in risk, but only among boys who were thin at birth. In these boys the adverse effects of rapid weight gain on later coronary heart disease are already apparent at age 3 years. Improvements in fetal, infant, and child growth could lead to substantial reductions in the incidence of coronary heart disease.
\end{abstract}

\section{Introduction}

Low birth weight is associated with increased rates of coronary heart disease in later life. ${ }^{1-8}$ This is thought to be a consequence of persisting physiological and metabolic changes that accompany slow growth in utero. ${ }^{9}$ Among men in Hertfordshire, where both birth weight and weight at age 1 year were recorded routinely, low weight at 1 year added to the increased risk of coronary heart disease associated with low birth weight. ${ }^{1}$ This association between low weight gain in infancy and later coronary heart disease has not been explored in other studies. We report here on associations between early growth and coronary heart disease in a cohort of 4630 men born in Helsinki during 1934-44, for whom serial measurements of height and weight from birth to age 12 years were recorded in obstetric, child welfare, and school health records.

\section{Methods}

We studied a sample of men who were born at Helsinki University Central Hospital during 1934-44 and who attended child welfare clinics in the city of Helsinki and were still resident in Finland in 1971. Details of the birth records kept at the hospital have been described. ${ }^{10}$ Attendance at child welfare clinics in Helsinki was voluntary. Clinic records include serial measurements of height and weight.

We identified 5502 men who had birth and child welfare records. Of these, $4630(84 \%)$ were alive and living in Finland in 1971, when a unique identification number was allocated to each member of the Finnish population; 3544 of these men went to school in Helsinki and had school health records. Details of school health records have been described. ${ }^{5}$ They include measurements of height and weight recorded at periodic medical examinations from age 6 years onwards.

Using the personal identification number, we identified all hospital admissions and deaths among the men during 1971-97. All hospital admissions in Finland are recorded in the national hospital discharge register. All deaths are recorded in the national mortality register. Causes of hospital admissions or deaths were recorded according to ICD-8 (international classification of diseases, eighth revision) until 1986; thereafter ICD-9 was used until 1995 and ICD-10 until 1997. The first three digits from the cause of admission or death were used to identify the occurrence of coronary heart disease (ICD-8 and ICD-9 codes 410-414, ICD-10 code I21-I25).

We obtained ethical approval for the study from the ethical committee of the National Public Health Institute, Helsinki.

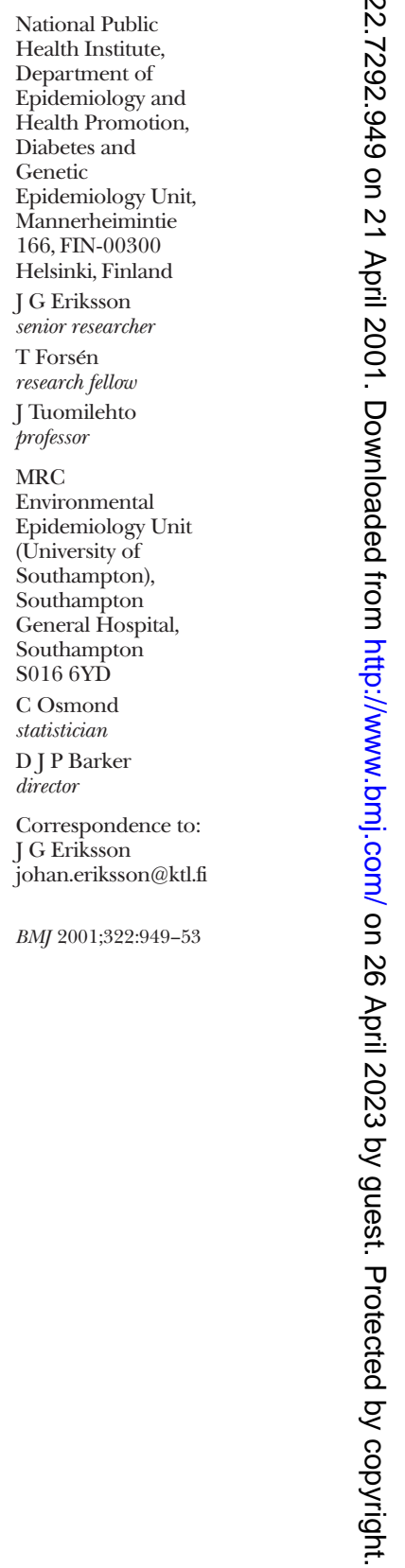




\section{Statistical analyses}

We examined trends in hazard ratios with neonatal and childhood measurements using Cox's proportional hazards model. ${ }^{11}$ As in previous analyses, ${ }^{5}$ we converted each measurement of height, weight, and body mass index (weight $(\mathrm{kg}) /\left(\right.$ height $\left.(\mathrm{m})^{2}\right)$ ) for each boy to a $\mathrm{Z}$ score at each birthday. Z scores represent the difference from the mean value for the whole cohort, expressed

Table 1 Neonatal and infant characteristics of 4630 men born at Helsinki University Central Hospital during 1934-44

\begin{tabular}{lccc} 
& Mean (SD) & Range & $\begin{array}{c}\text { No of missing } \\
\text { values }\end{array}$ \\
\hline Neonates: & & & \\
\hline Birth weight $(\mathrm{g})$ & $3456(490)$ & $1290-5180$ & 0 \\
\hline Head circumference $(\mathrm{cm})$ & $35.4(1.5)$ & $28-42$ & 70 \\
\hline Birth length $(\mathrm{cm})$ & $50.6(2.0)$ & $41-59$ & 56 \\
\hline Ponderal index $\left(\mathrm{kg} / \mathrm{m}^{3}\right)$ & $26.5(2.2)$ & $16.8-50.3$ & 56 \\
\hline Placental weight $(\mathrm{g})$ & $653(121)$ & $240-1150$ & 18 \\
\hline Length of gestation (days) & $280(11)$ & $251-309$ & 298 \\
\hline Infants $(\mathrm{age} 1$ year): & & 9 \\
\hline Height $(\mathrm{cm})$ & $76.2(3.0)$ & $64.1-89.0$ & 9 \\
\hline Weight $(\mathrm{kg})$ & $10.4(1.5)$ & $5.0-17.9$ & 9 \\
\hline Body mass index $\left(\mathrm{kg} / \mathrm{m}^{2}\right)$ & $17.7(1.7)$ & $11.7-25.9$ & \\
\hline
\end{tabular}

Table 2 Hazard ratios for coronary heart disease according to body size at birth

\begin{tabular}{lcc} 
& $\begin{array}{c}\text { Hazard ratios } \\
\mathbf{( 9 5 \%} \mathbf{~ C l})\end{array}$ & No of cases/No of men \\
\hline Birth weight $(\mathrm{g}):$ & $3.63(2.02$ to 6.51$)$ & \\
\hline$\leqslant 2500$ & $1.83(1.09$ to 3.07$)$ & $24 / 160$ \\
\hline-3000 & $1.99(1.26$ to 3.15$)$ & $145 / 599$ \\
\hline-3500 & $2.08(1.31$ to 3.31$)$ & $123 / 17558$ \\
\hline-4000 & 1.00 & \\
\hline$>4000$ & 0.006 & $104 / 1093$ \\
\hline$P$ for trend & $1.66(1.11$ to 2.48$)$ & $84 / 1260$ \\
\hline Ponderal index $\left(\mathrm{kg} / \mathrm{m}^{3}\right):$ & $1.44(0.97$ to 2.13$)$ & $31 / 578$ \\
\hline$\leqslant 25$ & $1.18(0.78$ to 1.78$)$ & \\
\hline-27 & 1.00 & \\
\hline-29 & 0.0006 & \\
\hline$>29$ & & \\
\hline$P$ for trend & & \\
\hline
\end{tabular}

Table 3 Hazard ratios for coronary heart disease according to body size at one year

\begin{tabular}{lcc} 
& $\begin{array}{c}\text { Hazard ratio } \\
(\mathbf{9 5} \% \text { Cl) }\end{array}$ & No of cases/No of men \\
\hline Weight $(\mathrm{kg}):$ & & $96 / 781$ \\
\hline$\leqslant 9$ & $1.82(1.25$ to 2.64$)$ & $85 / 1126$ \\
\hline-10 & $1.17(0.80$ to 1.71$)$ & $89 / 1243$ \\
\hline-11 & $1.12(0.77$ to 1.64$)$ & $49 / 852$ \\
\hline-12 & $0.94(0.62$ to 1.44$)$ & $38 / 619$ \\
\hline$>12$ & 1.00 & \\
\hline$P$ for trend & $<0.0001$ & $79 / 636$ \\
\hline Height $(\mathrm{cm}):$ & & $68 / 962$ \\
\hline$\leqslant 73$ & $1.55(1.11$ to 2.18$)$ & $87 / 1210$ \\
\hline-75 & $0.90(0.63$ to 1.27$)$ & $64 / 1011$ \\
\hline-77 & $0.94(0.68$ to 1.31$)$ & $59 / 802$ \\
\hline-79 & $0.83(0.58$ to 1.18$)$ & \\
\hline$>79$ & 1.00 & $72 / 654$ \\
\hline$P$ for trend & 0.007 & $89 / 936$ \\
\hline Body mass index $\left(\mathrm{kg} / \mathrm{m}^{2}\right):$ & & $83 / 1136$ \\
\hline$\leqslant 16$ & $1.83(1.28$ to 2.60$)$ & $59 / 941$ \\
\hline-17 & $1.61(1.15$ to 2.25$)$ & $54 / 954$ \\
\hline-18 & $1.29(0.91$ to 1.81$)$ & \\
\hline-19 & $1.12(0.77$ to 1.62$)$ & \\
\hline$>19$ & 1.00 & \\
\hline$P$ for trend & 0.0004 & \\
\hline
\end{tabular}

in standard deviations. ${ }^{12}$ We did not assign a $\mathrm{Z}$ score at a particular age if the boy had not been measured within two years of that age.

\section{Results}

Table 1 shows the neonatal and infant characteristics of the 4630 men. Each man had on average 9.3 (SD 6.6) measurements of height and weight between birth and age 1 year, 2.9 (3.8) measurements from age 1 year to 6 years and 5.8 (3.9) measurements from age 6 to 12 years. After that age school medical examinations were less frequent. In all, 288 of the men had been admitted to hospital with coronary heart disease, of whom 42 died of the disease. A further 69 had died without admission to hospital. We therefore analysed data on 357 men with coronary heart disease. The annual death rate from the disease at ages 45 to 54 years was 1.6 per 1000 .

\section{Size at birth}

Table 2 shows hazard ratios for coronary heart disease according to size at birth. The hazard ratios fell with increasing birth weight and ponderal index (birth weight $(\mathrm{kg}) /\left(\right.$ length $\left.\left.(\mathrm{m})^{3}\right)\right)$. These trends were found in babies born at term or prematurely and therefore reflected low rates of intrauterine growth. Hazard ratios also fell with increasing head circumference $(\mathrm{P}=0.002$, adjusted for gestation), but there were no trends with length at birth or placental weight.

\section{Size at age 1 year}

Table 3 shows that hazard ratios for coronary heart disease fell progressively with increasing weight, height, and body mass index at age 1 year. Small body size at this age predicted coronary heart disease independently of size at birth. In a simultaneous analysis the hazard ratios for coronary heart disease associated with a one standard deviation increase were 0.94 (95\% confidence interval 0.83 to 1.06 ) for birth weight and 0.84 ( 0.75 to 0.94$)$ for weight at 1 year. The corresponding figures for ponderal index at birth and body mass index at 1 year were $0.86(0.77$ to 0.97$)$ and 0.87 (0.78 to 0.96$)$.

\section{Childhood growth}

Figure 1 shows the childhood growth, expressed as mean $\mathrm{Z}$ scores, of the men who developed coronary heart disease. The $\mathrm{Z}$ score for the cohort is set at zero, and a boy maintaining a steady position as large or small in relation to other boys would follow a horizontal path on the figure. Boys who later developed coronary heart disease, however, having been small at birth and during infancy, had accelerated gain in weight and body mass index thereafter. In contrast, their heights remained below average, this difference being significant at each age from 1 to 5 years. We calculated the hazard ratios for coronary heart disease associated with gain in body mass index between the ages of 1 and 12 years. A one unit increase in standard deviation score was associated with a hazard ratio of 1.20 (1.08 to $1.33 ; \mathrm{P}=0.0005)$.

In our earlier analyses of an older cohort of men born in Helsinki, whose childhood growth was recorded only from age 7 years onwards, we found that the effects of childhood body mass index on later coronary heart disease depended on ponderal index at 


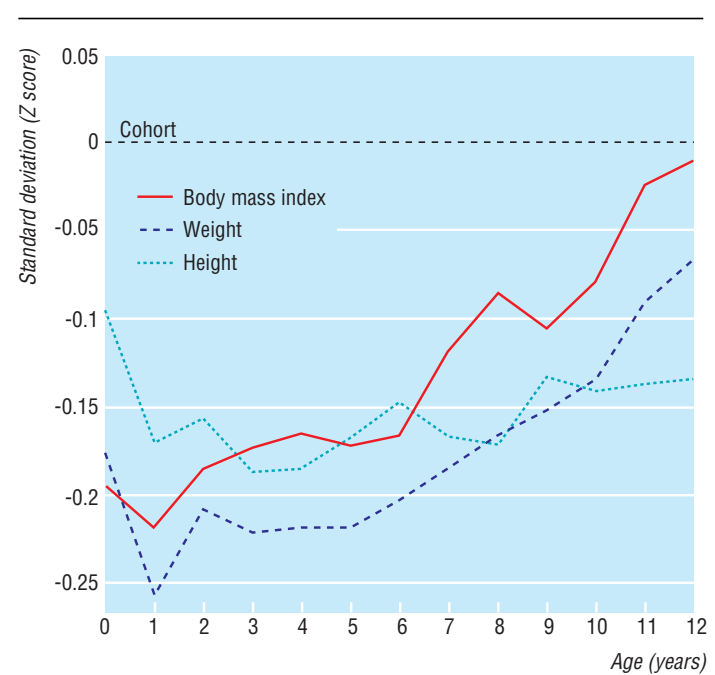

Fig 1 Growth of 357 boys who later developed coronary heart disease in a cohort of 4630 boys born in Helsinki

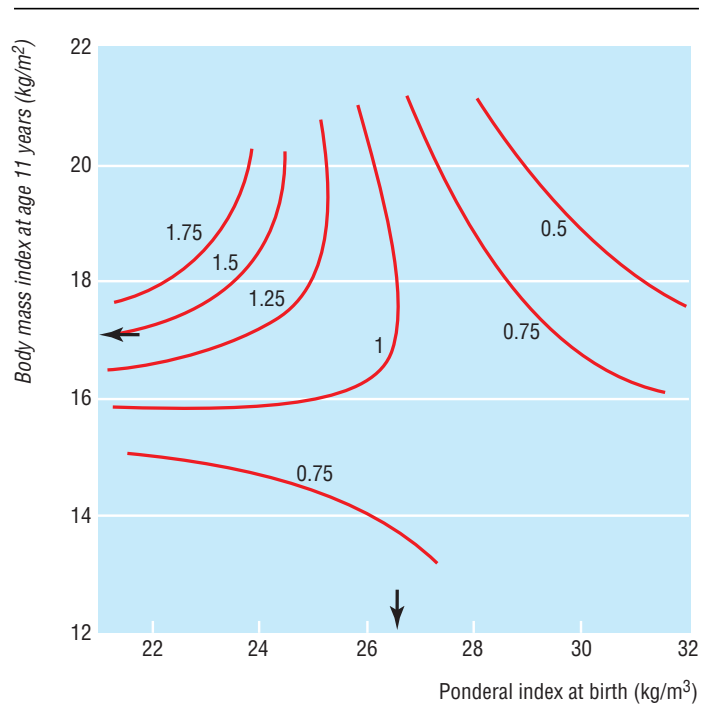

Fig 2 Hazard ratios for coronary heart disease according to ponderal index at birth and body mass index at age 11 years. Arrows indicate average values; lines join points with the same hazard ratios

birth. ${ }^{5}$ In the current analysis we therefore examined the simultaneous effects of ponderal index at birth and body mass index at each age. We found significant interactions between the two variables from age 2 years onwards. Figure 2 illustrates this. Boys who had a low ponderal index at birth increased their risk of coronary heart disease if they attained even average body mass index in childhood. In contrast, among boys with a high ponderal index there was no increased risk associated with increase in body mass index. Figure 2 describes body mass index at age 11 years, for consistency with studies of the older cohort, but data for other ages are similar. These are shown in table 4 , in which the cohort is divided according to ponderal index at birth, using an index of 26 as the division. This division gives similar numbers of cases of coronary heart disease in the two groups.
Table 4 shows the hazard ratios for coronary heart disease associated with a standard deviation increase in body mass index at each age from 1 to 12 years. In the low ponderal index group an increase in body mass index at each age from 3 years onwards was associated with increased risk of disease, whereas in the high ponderal index group an increase in body mass index at any age was associated with reduced risk. Table 5 illustrates these contrasting effects of body mass index at the middle of the age range. At this and all other ages the boys who could not be assigned $\mathrm{Z}$ scores were similar to the others in their body size at birth and in their later incidence of coronary heart disease.

\section{Discussion}

We have examined the infant and childhood growth of 357 men who were either admitted to hospital with coronary heart disease or who died of the disease. The men belonged to a cohort of 4630 men whose growth was measured serially from birth to age 12 years, there being on average 18 measurements of height and weight for each man. This is the first time that the early growth of boys who later developed coronary heart disease has been documented by serial measurements. We found two paths of growth associated with coronary heart disease. In one, thinness at birth was followed by rapid weight gain in childhood. In the other, failure of infant growth was followed by persisting thinness during childhood. Both were associated with short stature in childhood.

\section{Limitations of study}

Our study was restricted to men who were born in Helsinki University Hospital, where about $60 \%$ of all

Table 4 Hazard ratios (95\% confidence intervals) for coronary heart disease according to one standard deviation increases in body mass index during childhood

\begin{tabular}{|c|c|c|c|}
\hline \multirow[b]{2}{*}{ Age (years) } & \multicolumn{2}{|c|}{ Ponderal index at birth } & \multirow[b]{2}{*}{ All } \\
\hline & $<26(n=1851)$ & $>26(n=2723)$ & \\
\hline 1 & $0.89(0.77$ to 1.04$)$ & 0.80 (0.69 to 0.93$)$ & 0.83 (0.75 to 0.92$)$ \\
\hline 2 & $0.99(0.84$ to 1.16$)$ & 0.77 (0.66 to 0.89$)$ & 0.84 (0.76 to 0.94$)$ \\
\hline 3 & $1.06(0.90$ to 1.25$)$ & 0.73 (0.63 to 0.85$)$ & 0.85 (0.76 to 0.95$)$ \\
\hline 4 & 1.09 (0.93 to 1.29$)$ & 0.75 (0.64 to 0.88$)$ & 0.87 (0.78 to 0.98$)$ \\
\hline 5 & $1.13(0.95$ to 1.34$)$ & $0.73(0.62$ to 0.86$)$ & 0.87 (0.77 to 0.98$)$ \\
\hline 6 & $1.19(1.01$ to 1.41$)$ & $0.70(0.59$ to 0.84$)$ & 0.89 (0.79 to 1.00$)$ \\
\hline 7 & $1.22(1.03$ to 1.44$)$ & 0.75 (0.63 to 0.90$)$ & 0.94 (0.83 to 1.06) \\
\hline 8 & 1.23 (1.04 to 1.45$)$ & 0.80 (0.66 to 0.95$)$ & 0.97 (0.86 to 1.10$)$ \\
\hline 9 & 1.20 (1.02 to 1.43$)$ & 0.77 (0.64 to 0.93$)$ & 0.94 (0.83 to 1.07$)$ \\
\hline 10 & 1.22 (1.03 to 1.46$)$ & 0.81 (0.67 to 0.97$)$ & 0.97 (0.86 to 1.10$)$ \\
\hline 11 & 1.23 (1.05 to 1.45$)$ & 0.87 (0.73 to 1.05$)$ & 1.02 (0.90 to 1.16$)$ \\
\hline$\overline{12}$ & $1.23(1.04$ to 1.46$)$ & 0.89 (0.74 to 1.07$)$ & 1.03 (0.91 to 1.17$)$ \\
\hline
\end{tabular}

Table 5 Hazard ratios (95\% confidence interval) for coronary heart disease according to ponderal index at birth and body mass index at age 6 years

\begin{tabular}{|c|c|c|c|c|}
\hline \multirow[b]{3}{*}{$\begin{array}{l}\text { Body mass index } \\
\text { at age } 6 \text { years }\end{array}$} & \multicolumn{4}{|c|}{ Ponderal index at birth } \\
\hline & \multicolumn{2}{|c|}{$<26.0$} & \multicolumn{2}{|c|}{$>26.0$} \\
\hline & Hazard ratio & $\begin{array}{c}\text { No of cases/No } \\
\text { of men }\end{array}$ & Hazard ratio & $\begin{array}{c}\text { No of cases/No } \\
\text { of men }\end{array}$ \\
\hline$\leqslant 13.6$ & 1.67 (0.94 to 2.99$)$ & $25 / 362$ & 2.54 (1.47 to 4.38$)$ & $34 / 307$ \\
\hline-14.2 & 2.17 (1.24 to 3.79$)$ & $30 / 318$ & 1.80 (1.04 to 3.12$)$ & $32 / 409$ \\
\hline-14.8 & $2.00(1.12$ to 3.57$)$ & $25 / 300$ & $1.94(1.14$ to 3.31$)$ & $37 / 472$ \\
\hline-15.4 & 3.50 (2.04 to 6.02 ) & $35 / 236$ & 1.27 (0.71 to 2.27$)$ & $25 / 462$ \\
\hline$>15.4$ & 2.48 (1.35 to 4.54$)$ & $21 / 228$ & 1.00 & $21 / 542$ \\
\hline $\mathrm{P}$ for trend & 0.04 & & 0.0001 & \\
\hline
\end{tabular}


births in the city occurred. This would introduce a bias only if the association between early growth and coronary heart disease differed between those born in the hospital and those born outside it. Our study was further restricted to men who had attended child welfare clinics, which were voluntary. The men may therefore be unrepresentative of all men living in Helsinki. In particular, attendance at child welfare clinics could have been related to socioeconomic circumstances. Poorer families may have made more use of the clinics because their children were less healthy, or better educated mothers may have been more willing to take advice on child rearing. We know that most of the children who attended the clinics did so regularly as each child had an average of 12 recorded measurements of height and weight. Similarly to the older cohort, however, we also have data on the occupations of the fathers of the men, at the time of the birth; $66 \%$ of the fathers were labourers. We know that at this time in Helsinki around $60 \%$ of men were labourers ${ }^{11}$ and the social class distribution of our sample may therefore be similar to that of the city as a whole. Of the boys we identified through birth and clinic records, $84 \%$ were still alive and resident in Finland in 1971.

\section{Consistency with other studies}

Associations between low birth weight, low ponderal index, and later coronary heart disease (table 2) have been shown in other studies. ${ }^{1-8}$ The association with slow growth during infancy is consistent with findings among men in Hertfordshire, where low weight at age 1 year similarly added to the increased risk of coronary heart disease associated with low birth weight. ${ }^{13}$ The size of the simultaneous effects of birth weight and weight at age 1 in the Hertfordshire study was similar to the size of those in Helsinki. We have replicated the association between coronary heart disease and rapid growth in weight and body mass index after age 6 years, an association first shown in the older Helsinki cohort. ${ }^{5}$ We have now shown that the adverse effect of this association is evident by age 3 years and is confined to boys who were thin at birth (ponderal index <26). The association we found between low rates of height growth in early childhood (fig 1) and later coronary heart disease is consistent with the known association between the disease and short adult stature in men and short leg length measured in childhood. ${ }^{14-16}$

\section{Mechanics}

Several possible mechanisms exist by which reduced fetal and infant growth and accelerated weight gain in childhood may lead to coronary heart disease. Babies who are thin at birth lack muscle, a deficiency which will persist, as the critical period for muscle growth is around 30 weeks in utero and there is little cell replication after birth. ${ }^{17}$ If they develop a high body mass index in childhood they may have a disproportionately high fat mass. This may be associated with the development of insulin resistance, as children and adults who had low birth weight but are currently heavy are insulin resistant. ${ }^{18} 19$

Among men with a ponderal index at birth of $>26$, low body mass index in infancy and childhood was associated with increased risk of coronary heart

\section{What is already known on this topic}

Coronary heart disease is associated with low birth weight

One study has shown that irrespective of size at birth, low weight gain in infancy is also associated with increased risk of the disease among men

Rapid weight gain after age 6 years is associated with further increase in risk

\section{What this study adds}

The association with low weight gain in infancy is confirmed

The adverse effects of rapid childhood weight gain on risk of coronary heart disease are already apparent at age 3 years and occur only in boys who were thin at birth

disease. Findings in Hertfordshire suggest that the process underlying this may be disturbance of lipid metabolism and blood coagulation. Among men in Hertfordshire, low weight at age 1 year was associated with raised serum concentrations of total and low density lipoprotein cholesterol and apolipoprotein B, and also with raised plasma fibrinogen concentrations..$^{20}$ Circulating low density lipoprotein cholesterol and fibrinogen concentrations are regulated by the liver, and one possibility is that the high concentrations associated with low infant weight gain are persisting responses to impaired liver development during a critical phase in fetal life and infancy. ${ }^{21}$ During its development the liver remains "plastic" until about age 5 years, and its function may therefore be permanently changed by influences which affect its early growth. ${ }^{22-24}$ Support for an important role for liver development in the early pathogenesis of coronary heart disease comes from findings among people born at the Jessop Hospital, Sheffield. ${ }^{25-27}$

\section{Conclusion}

The interaction between ponderal index at birth and childhood body mass index shows that the pathogenesis of coronary heart disease cannot be understood within a "cumulative" model in which risks associated with adverse influences at different stages of life add to each other. ${ }^{28}$ Rather, the consequences of some influences, including a high body mass in childhood, depend on events at early critical stages of development. This embodies the concept of developmental "switches" triggered by the environment. ${ }^{29}$

We have found that gain in weight and body mass index during infancy are associated with reduced risk of coronary heart disease (table 3). This reduction occurs irrespective of body size at birth (table 4). This is important because promoting weight gain in infancy is standard practice. The associations between fetal and infant growth and later coronary heart disease in this study are strong and graded. Boys who at birth had a ponderal index $>26$ and who at age 1 year were above the cohort average for height (76.2 $\mathrm{cm})$ and body mass index (17.7) had half the risk of coronary heart disease occurring before age 65 years. 
These are not unrealistic growth targets for public health interventions. There are obvious reservations about quantifying possible benefit in European populations today from observations made in Finland 40 to 50 years ago. Nevertheless these estimates of risk reduction may be compared with the much smaller estimates of the effects of improvements in adult lifestyle. ${ }^{30}$ Our findings add to the evidence that protection of fetal and infant growth is a key area in strategies for the primary prevention of coronary heart disease. Further benefit will come from preventing rapid weight gain after infancy in boys who were thin at birth. In these boys the adverse effects of rapid weight gain on later coronary heart disease are already apparent at age 3 years.

We thank Terttu Nopanen, Tïna Saarinen, Hillevi ÖfverströmAnttila, Arja Purtonen, Tiina Valle, Hanna Pehkonen, and Ulla Tarvainen for abstracting the data from the records. Sigrid Rosten was responsible for data management. Liisa Toivanen coordinated data abstraction.

Contributors: All the authors took part in the design and analysis of the study and jointly wrote the paper. JGE and TF supervised the data abstraction and linkage. JGE, CO, and DJPB will act as guarantors for the paper.

Funding: British Heart Foundation, Jahnsson Foundation, Finnish Medical Society, Novo Foundation.

Competing interests: None declared.

1 Barker DJP, Osmond C, Winter PD, Margetts B, Simmonds SJ. Weight in infancy and death from ischaemic heart disease. Lancet 1989;2:577-80.

2 Leon DA, Lithell HO, Vagero D, Koupilova I, Mohsen R, Berglund L, et al Reduced fetal growth rate and increased risk of death from ischaemi heart disease: cohort study of 15000 Swedish men and women born 1915-29. BMJ 1998;317:241-5.

3 Rich-Edwards JW, Stampfer MJ, Manson JE, Rosner B, Hankinson SE, Colditz GA, et al. Birth weight and risk of cardiovascular disease in a cohort of women followed up since 1976. BMJ 1997;315:396-400.

4 Stein CE, Fall CHD, Kumaran K, Osmond C, Cox V, Barker DJP. Fetal growth and coronary heart disease in south India. Lancet 1996;348:1269 73.

5 Eriksson JG, Forsen T, Tuomilehto J, Winter PD, Osmond C, Barker DJP. Catch-up growth in childhood and death from coronary heart disease: longitudinal study. BMJ 1999;318:427-31.

6 Forsen T, Eriksson JG, Tuomilehto J, Osmond C, Barker DJP. Growth in utero and during childhood among women who develop coronary heart disease: longitudinal study. BMJ 1999;319:1403-7.

7 Frankel S, Elwood P, Sweetnam P, Yarnell J, Davey Smith G. Birthweight, adult risk factors and incident coronary heart disease: the Caerphilly study. Public Health 1996;110:139-43.

8 Martyn CN, Barker DJP, Osmond C. Mothers' pelvic size, fetal growth, and death from stroke and coronary heart disease in men in the UK. Lancet 1996;348:1264-8.
9 Barker DJP. Fetal origins of coronary heart disease. BMJ 1995;311: 171-4.

10 Forsen T, Eriksson JG, Tuomilehto J, Teramo K, Osmond C, Barker DJP. Mother's weight in pregnancy and coronary heart disease in a cohort of Finnish men: follow up study. BMJ 1997;315:837-40.

11 Cox DR. Regression models and life-tables. $J R$ Stat Soc Ser $B$ 1972;34:187-220.

12 Royston P. Constructing time-specific reference ranges. Stat Med 1991;10:675-90.

13 Osmond C, Barker DJP, Winter PD, Fall CHD, Simmonds SJ. Early growth and death from cardiovascular disease in women. BMJ 1993;307:151924

14 Marmot MG, Shipley MJ, Rose G. Inequalities in death-specific explanations of a general pattern? Lancet 1984;i:1003-6.

15 Gunnell D, Davey Smith G, Frankel S, Nanchahal K, Braddon FEM, Pemberton J, et al. Childhood leg length and adult mortality from cancer follow-up of the Carnegie (Boyd Orr) survey of diet and health in pre-war Britain. J Epidemiol Community Health 1998;52:142-52.

16 Tanner JM. Foetus into man. 2nd ed. Castlemead: Ware, 1989.

17 Widdowson EM, Crabb DE, Milner RDG. Cellular development of some human organs before birth. Arch Dis Child 1972;47:652-5.

18 Barker DJP, Hales CN, Fall CHD, Osmond C, Phipps K, Clark PMS. Type 2 (non-insulin-dependent) diabetes mellitus, hypertension and hyperlipidaemia (syndrome X): relation to reduced fetal growth. Diabetologia 1993;36:62-7.

19 Bavdekar A, Chittaranjan S, Fall CHD, Bapat S, Pandit AN, Deshpande V, et al. Insulin resistance syndrome in 8-year-old Indian children. Small at birth, big at 8 years, or both? Diabetes 1999;48:2422-9.

20 Fall CHD, Barker DJP, Osmond C, Winter PD, Clark PMS, Hales CN. Relation of infant feeding to adult serum cholesterol concentration and death from ischaemic heart disease. BMJ 1992;304:801-5.

21 Barker DJP, Meade TW, Fall CHD, Lee A, Osmond C, Phipps K, et al. Relation of fetal and infant growth to plasma fibrinogen and factor VII concentrations in adult life. $B M J$ 1992:304:148-52.

22 Gebhardt R. Metabolic zonation of the liver: regulation and implications for liver function. Pharmacol Therapeut 1992;53:275-354.

23 Desai M, Crowther NJ, Ozanne SE, Lucas A, Hales CN. Adult glucose and lipid metabolism may be programmed during fetal life. Biochem Soc Trans 1995;23:331-5.

24 Kind KL, Clifton PM, Katsman AI, Tsiounis M, Robinson JS, Owens JA. Restricted fetal growth and the response to dietary cholesterol in the guinea pig. Am J Physiol 1999;277:R1675-82.

25 Barker DJP, Martyn CN, Osmond C, Hales CN, Fall CHD. Growth in utero and serum cholesterol concentrations in adult life. $B M J$ 1993;307:1524-7

26 Martyn CN, Meade TW, Stirling Y, Barker DJP. Plasma concentrations of fibrinogen and factor VII in adult life and their relation to intra-uterine growth. Br J Haematol 1995;89:142-6.

27 Barker DJP, Martyn CN, Osmond C, Wield GA. Abnormal liver growth in utero and death from coronary heart disease. BMJ 1995;310:703-4.

28 Kuh D, Ben-Shlomo Y, eds. A life-course approach to chronic disease epidemiology. Oxford: Oxford University Press, 1997.

29 Bateson P, Martin P. Design for a life: how behaviour develops. London: Vintage, 1999.

30 Hooper L, Summerbell CD, Higgins JPT, Thompson RL, Capper NE, Davey Smith G, et al. Dietary fatintake and prevention of cardiovascular disease: systematic review. BMJ 2110;322:737-63.

(Accepted 4 April 2001)

\section{One hundred years ago}

\section{Perspective in medical education}

Dr. Andrewes said: My first and most pleasant duty is to bid a hearty welcome to the newcomers to this school, and I trust that you will gain here not only adequate training in the profession you have chosen which this school is now more than ever fitted to give you, but also a number of firm friendships and pleasant memories which will remain for your whole lives. I have next to say something to you-not new, indeed, but I hope true-about the methods of medical education, and especially about the value of a rational perspective in your studies. The enthusiasm for work, which I have found even keener amongst women students than amongst men, entails the risk that you may spend time over things that matter little, leaving insufficient space for more vital matters. It should be the main function of your teachers to direct your energies into the most important channels. No one can in five, or even in fifty, years learn all that one could wish about disease and its prevention and treatment. You have to go on learning all your lives, and, a healthy sense of ignorance is a saving grace. But there are three things which you must learn in your five years of medical study. You have to learn how to learn. Then you have to learn as much as you can of those things which are of immediate and cardinal importance, and which will serve as the groundwork for future learning after you commence practice. Lastly, you have to learn how to set forth what you have learned in such a manner as to persuade a Board of Examiners that you are fit and proper persons to be let loose on the public as qualified medical practitioners.

(BMJ 1901;ii:990) 